\title{
Examination of Failed Six Inch Cast Iron Pipe Natural Gas Main, Atlanta Gas Light Company, Atlanta, Georgia
}

T. Robert Shives

Mechanical Properties Section Metallurgy Division

Institute for Materials Research

National Bureau of Standards

Washington, D. C. 20234

April 20, 1973

Failure Analysis Report

Prepared for

Bureau of Surface Transportation National Transportation Safety Board Department of Transportation

Washington, D. C. 20591 



\section{EXAMINATION OF FAILED SIX INCH CAST IRON PIPE NATURAL GAS MAIN, ATLANTA GAS LIGHT COMPANY, ATLANTA, GEORGIA}

T. Robert Shives

Mechanical Properties Section

Metallurgy Division

Institute for Materials Research

National Bureau of Standards

Washington, D. C. 20234

April 20, 1973

Failure Analysis Report

"This document has been prepared for the use of the Bureau of Surface Transportation, National Transportation Safety Board, Department of Transportation, Washington, D. C. Responsibility for its further use rests with that agency. NBS requests that if release to the general public is contemplated, such action be taken only after consultation with the Office of Public Affairs at the National Bureau of Standards."

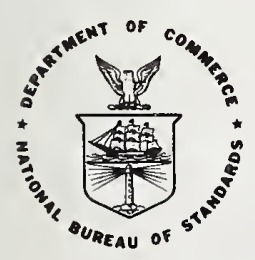



1. INTRODUCTION $\ldots \ldots \ldots \ldots \ldots \ldots \ldots \ldots \ldots \ldots \ldots \ldots \ldots \ldots \ldots \ldots \ldots \ldots$

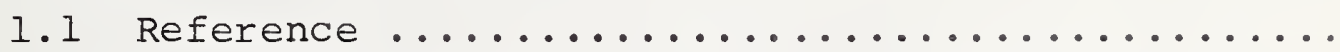

1.2 Part Submitted

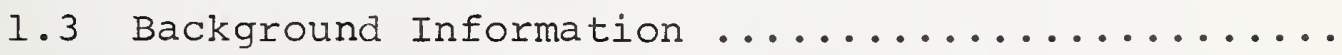

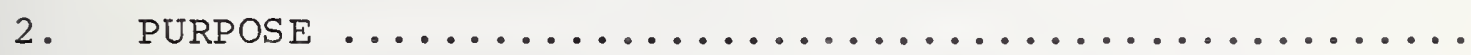

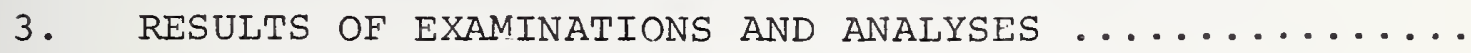

3.1 Visual Examination $\ldots \ldots \ldots \ldots \ldots \ldots \ldots \ldots$

3.2 Macroscopic Examination $\ldots \ldots \ldots \ldots \ldots \ldots \ldots$

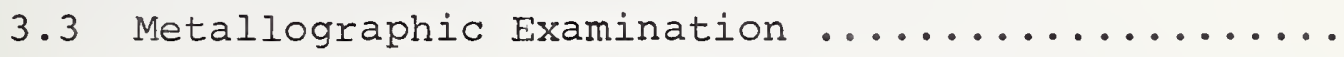

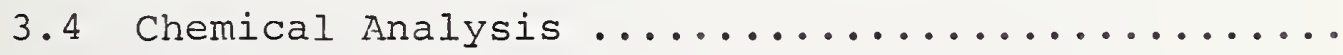

3.5 Hardness Measurements

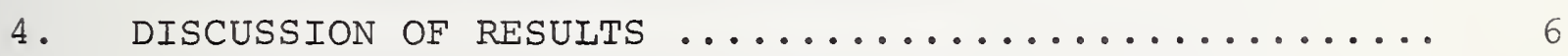

5. CONCLUSIONS $\ldots \ldots \ldots \ldots \ldots \ldots \ldots \ldots \ldots \ldots \ldots \ldots \ldots \ldots \ldots \ldots \ldots \ldots$

6. ACKNOWLEDGEMENT $\ldots \ldots \ldots \ldots \ldots \ldots \ldots \ldots \ldots \ldots \ldots \ldots$

REFERENCE

FIGURES

1. Length of pipe containing fracture as received .....

2. View of the two fractured pieces of pipe with the

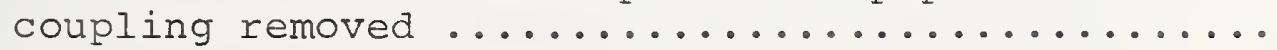

3. View of the inside of one of the fractured pieces

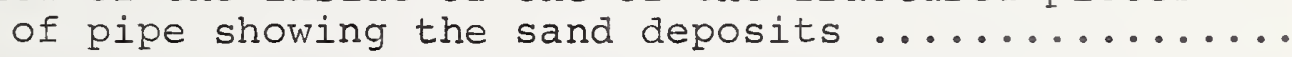

4. View of the inside of the same fractured piece of pipe as shown in figure 3 showing the sand deposits 

FIGURES (Continued)

5. One of the fracture faces $\ldots \ldots \ldots \ldots \ldots \ldots \ldots$

6. Fracture surface at top of pipe ............... 14

7. Part of one of the fracture surfaces ............ 15

8. Entire fracture surface after cleaning .......... 16

9. Photomacrographs of longitudinal cross sections intersecting the fracture surface ............

10. Polished transverse slice about one inch from

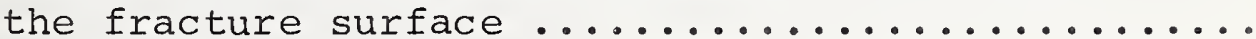

11. Polished transverse slice about eight inches

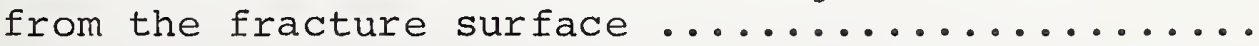

12. Unetched fields showing microstructure of

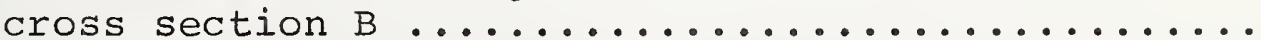

13. Unetched field from cross section D showing graphitization gradient

14. Unetched field from cross section $B \ldots \ldots . \ldots \ldots \ldots$

15. Etched field from cross section D near inside wall surface $\ldots \ldots \ldots \ldots \ldots \ldots \ldots \ldots \ldots \ldots \ldots \ldots$

16. Etched field from cross section D about midway between inside and outside wall surfaces.........

17. Etched field from cross section $D$ in an area where graphitization is beginning ...............

18. Etched field from cross section $D$ in an area where

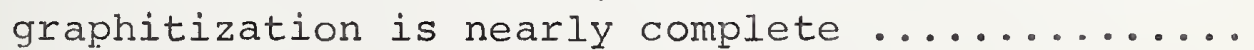



A five foot length of six inch grey cast iron pipe from a natural gas main which had failed in service was submitted for examination. The failure was from a pipeline which had been installed in Atlanta, Georgia in 1951.

The pipe had fractured transversely at the approyimate center of the submitted length. The opposing fracture faces were covered with soil and patches of a waxy appearing substance except for about a four inch circumferential length at the bottom of the pipe which appeared to be fresh fracture. The fracture apparently initiated at the top of the pipe and occurred in at least two stages, with the fresh fracture region being the last to fail.

There was sand deposited in one of the fractured pieces in a pattern that indicates that the piece had been rotated about its longitudinal axis.

Graphitization (corrosion), penetrating up to 30 percent of the wall thickness in one area, was found in all cross sections examined, although most of the material was free of graphitization. Where graphitization existed, it had started at the outside wall surface of the pipe. The most severely graphitized region found was adjacent to the fracture.

Nothing abnormal for grey cast iron was noted in the chemical composition, hardness, or microstructure of the material in the pipe.

The likely cause of failure was the application of an external load to produce a bending stress in an area of the pipe weakened by graphitization. 

Examination of Failed Six Inch Cast Iron Pipe Natural Gas Main, Atlanta Gas Light Company, Atlanta, Georgia

\section{INTRODUCTION}

\subsection{Reference}

Bureau of Surface Transportation, National Transportation Safety Board, Department of Transportation, Washington, D. C. This investigation was conducted under NTSB order no. AB3006 accepted by NBS on January 10, 1973.

1.2 Part Submitted

A fractured five foot length of six inch diameter cast iron pipe natural gas main was submitted to NBS for examination on september 21, 1972. The pipe had fractured completely in the approximate center of the submitted length. A coupling and seal which connected the two fractured parts of the pipeline was still in place at the time the pipe section was received at NBS.

\subsection{Background Information}

The information in this section was furnished by the Bureau of Surface Transportation via telephone conversations with T. R. Shives of the National Bureau of Standards.

The pipeline, which had been installed in 1951, was found to contain a fracture on August 31, 1972. This pipeline is composed of 16 foot lengths of six inch diameter cast iron pipe connected by mechanical joints. The section that fractured had been installed over a large concrete sewer line with about three inches clearance between the sewer and the gas main. Gas pressure in the line had been 10 psig. 



\section{PURPOSE}

failure.

The submitting agency requested an analysis of the

\section{RESULTS OF EXAMINATIONS AND ANALYSES}

\subsection{Visual Examination}

According to information obtained from the National Transportation safety Board, the plug in the coupling connecting the two fractured pieces was at the top of the pipe as it was positioned in the ground. Top and bottom views of the pipe length as received are shown in figures la and lb, respectively.

Much of the outer surface of the pipe was encrusted with a deposit which appeared, for the most part, to be soil. This deposit was generally yellowish-orange in color, but some areas were grey. Some of this material could be crumbled away with the fingers, but most of it adhered firmly to the pipe surface. The material did not appear to be deposited on the pipe in any particular pattern. Some of the deposit can be seen in figure 1 . The outside surface areas of the pipe not covered with the deposit were covered with a fairly thin scale.

Removal of the coupling revealed a relatively clean pipe surface where the coupling had been. This can be seen in figure 2 where the two fractured pieces are shown separated. At both edges of this clean length (where the edges of the coupling had been), there was a black ring (arrows, figure 2) of sealing material. The white chalk lines indicate the top of the pipe. The deposited material on the outer surface of the pipe which had not been covered by the coupling can also be seen in this figure. 

The inside surfaces of the two fractured pieces were covered with a light scale. One piece had sand adhering to the inside wall surface in a pattern which indicated that it had been rotated approximately a full turn about its longitudinal axis with the pipe essentially in a horizontal position while the sand was wet. As viewed from the fracture surface, and with reference to a clockwise rotation direction, most of the sand adhered to the wall surface in the $60^{\prime} \mathrm{clock}$ to 12 o'clock region. There was a small amount of sand between 12 'clock and 6 o'clock which appeared to have deposited after that at the first location, and after the sand had dried somewhat. Two views of the pipe exhibiting the sand pattern are shown in figures 3 and 4 . A one incin transverse slice containing the fracture surface had been removed before the photographs shown in figures 3 and 4 were taken. The sand pattern was not disturbed by the dry cutting of the slice. The second fractured piece did not exhibit this sand pattern, and no deposit of sand was observed in the gap between the fracture surfaces when the coupling was removed.

Both fracture faces were covered with what appeared to be soil (yellow clay in color) and a few patches of a grey, waxy appearing substance except for about a four inch circumferential length at the bottom which was bright and had the appearance of a fresh fracture. One of the fracture surfaces is shown in figure 5. The region appearing as fresh fracture is bracketed.

\subsection{Miacroscopic Examination}

There were some areas of mechanical damage on the fracture surfaces which may have been caused by the opposing faces contacting each other. The opposing surfaces had similar or mating features essentially everywhere except at the top of the pipe. There was a small chip(s) missing from the top outside surface (figure 6) at the fracture, and a small amount of material missing across the fracture between the opposing ialves.

One of the fracture surfaces and the adjacent inner and outer surfaces of the pipe were cleaned ultrasonically with detergent and water at NBS. After cleaning, the fracture had the brittle appearance to be expected from a grey cast iron fracture. The surface of the pipe under the missing chip was fairly bright with little apparent corrosion after cleaning. Figures $7 \mathrm{a}$ and $7 \mathrm{~b}$ show one part of the fracture surface before and after cleaning, respectively. The entire fracture surface after cleaning is shown in figure 8. 

Four longitudinal cross sections about one inch long each were cut to intersect the cleaned fracture surface. The locations of these are indicated in figure 8 . Various amounts of graphitization* were found in each of the cross sections, and in each case, there was graphitization adjacent to the fracture. Photomacrographs of parts of cross sections $A, C$, and $D$ are shown in figures $9 \mathrm{a}, 9 \mathrm{~b}$, and 9c, respectively. The degree of graphitization in cross section $B$ is intermediate to that in cross sections $A$ and $D$. There is graphitization evident under the missing chip (figure 9b). Where there was graphitization, it began at the outside wall surface and proceeded inward. It appeared as a gradient, the degree of graphitization aecreasing with distance from the outside wall surface.

The maximum depth of penetration in cross section $D$ was about $1 / 10$ inch, or about 25 percent of the wall thickness. The maximum depth of penetration in cross section $C$, including the depth of the missing chip, occurred adjacent to the fracture and was greater than $1 / 10$ inch (about 30 percent of the wall thickness). This was the greatest penetration of graphitization found in any of the cross iections examined.

Two transverse slices, at one inch and eight inches from the fracture, respectively, were examined for graphitization. There was some graphitization in both slices, but not at the top of the pipe in either case (figures 10 and 11). The deepest penetration (about $1 / 16$ inch, or 16 percent of the $3 / 8$ inch wall thickness) was found in the slice one inch from the fracture. This area is shown in the insert in figure 10.

\subsection{Metallographic Examination}

The four longitudinal cross sections that were examined macroscopically were also examined metallographically.

Unetched fields intersecting the outside and inside surfaces of the pipe are shown in figures $12 \mathrm{a}$ and $12 \mathrm{~b}$, respectively. The microstructures shown in figure 12 are representative of the four cross sections examined. Both of these fields are from cross section $B$, and the field shown in figure $12 \mathrm{a}$ is in an area where there was very little graphitization. The graphite flakes (dark phase) near the outside surface are of the $A, B$, and $C$ types (figure 12a). In the center of the wall thickness and near the inner wall surface, the graphite flakes are primarily of the $A$ and $C$ types (figure 12b).

The term "graphitization" as used in this report indicates a corrosion process. 
An unetched field from cross section D exhibiting graphitization at and adjacent to the outside pipe surface is shown in figure 13. The graphitization gradient is quite evident. Graphitization is essentially complete near the outside surface (at the left in the figure) and is just beginning about one-fourth of the distance in from the right. At the far right in the figure, there is no evidence of graphitization. Figure 14 (at a higher magnification than figure 13) shows an area where graphitization is beginning in cross section B. There is considerable corrosion product surrounding the graphite flakes.

Etched fields from cross section D which are representative of the four cross sections examined are shown in figures 15 through 18 (at higher magnifications than figures 12 and 13). The microstructure near the inside wall surface of the pipe (figure 15) consists of graphite flakes partially surrounded by ferrite (ligkt color) in a matrix of pearlite (grey) and iron-iron phosphide eutectic (light). Midway through the wall thickness, the microstructure consists of graphite flakes in a matrix composed primarily of pearlite and iron-iron phosphide eutectic (figure 16). An etched field (at a lower magnification than figures 15 and 16) where graphitization is beginning shows graphite flakes surrounded by corrosion product (figure 17). The matrix is again composed of pearlite and iron-iron phosphide eutectic. An area where graphitization is nearly complete is shown in figure 18. There is still a small amount of the iron-iron phosphide eutectic component of the matrix remaining.

3. 4 Chemical Analysis

A sample from the pipe was analyzed for chemical composition by a commercial laboratory using spectrographic and other techniques. The results of that analysis are as follows:

Element

Carbon, total

Carbon, combined

Manganese

Phosphorus

Sulfur

Silicon

Nickel

Chromium

Molybdenum

Copper

\section{Percent}

$$
\begin{array}{ll} 
& 3.26 \\
& 0.80 \\
0.34 & 0.64 \\
& 0.64 \\
0.085 & 1.30 \\
& 0.06 \\
< & 0.05 \\
< & 0.05 \\
& 0.10
\end{array}
$$

The results of the chemical analysis indicate that the material is an unalloyed grey cast iron. 

Rockwell $\mathrm{B}\left(\mathrm{R}_{\mathrm{B}}\right)$ hardness measurements were made on a cross section through the pipe wall. The hardness ranged from about $R_{B} 92.5$ near the inside wall surface to about $R_{B}$ 94.5 in the center of the wall thickness to about $R_{B} 98$ near the outside wall surface.

\section{DISCUSSION OF RESULTS}

The most deleterious condition found in the material examined from the submitted length of pipe was graphitization. All four longitudinal cross sections examined revealed graphitization adjacent to the fracture. Graphitization was also found in two transverse slices taken parallel to, and one and eight inches from the fracture.

The deepest penetrations of the graphitization were about $1 / 10$ inch in cross section $D$ and slightly greater than $1 / 10$ inch in cross section $C$ (including the depth of the missing chip). The penetration in cross section $C$ represents about 30 percent of the $3 / 8$ inch wall thickness. The deepest penetration in either of the two transverse slices was about 1/16 inch found in the slice taken one inch from the fracture.

Most areas of the cross sections adjacent to the outside wall surface, but away from the fracture surface, exhibited no graphitization. Where graphitization was found, it started at the outside surface of the pipe and proceeded inward. It occurred as a gradient, the severity being essentially inversely proportional to the distance from the outside wall surface of the pipe.

The pattern of the sand adhering to the inside wall surface of one of the fractured pieces indicates that the piece was apparently rotated approximately a full turn about its longitudinal axis while in a horizontal position. There was no sand in the second piece, nor was sand observed in the fracture gap at the time of disassembly. This sand pattern appears to have no bearing on the failure of the pipe.

Chemical analysis indicated that the pipe material was an unalloyed grey cast iron. The chemical composition does not appear to fit the chemical composition limits for any of the ASTM class 20 through 60 grey cast irons. I 

The results of the hardness measurements indicate a hardness gradient from about $R_{B} 98$ near the outside wall surface to about $\mathrm{RB} 92.5$ near the inside wall surface. This difference does not appear to be of any great significance.

The microstructure of the material from the pipe in the areas which had not become graphitized appeared to be normal for grey cast iron.

This gas main pipe apparently failed from the application of an external load which produced a bending stress in an area weakened by graphitization. The source of the external load might have been, among other things, settling of the soil around the pipe or movement of heavy equipment over the pipe.

The deposits of soil and a waxy appearing substance on the upper three-fourths of the fracture surfaces indicate that the fracture probably initiated at the top of the pipe. The fresh fracture appearance at the bottom indicates that this was probably the last part to fail. The elapsed time between the fracture initiation and final failure is not known.

\section{CONCLUSIONS}

1. Although most of the material adjacent to the outside wall surface of the pipe exhibited no graphitization, the four longitudinal cross sections examined which intersected the fracture showed graphitization adjacent to the fracture.

2. Some graphitization was found in transverse slices through the pipe one inch and eight inches from the fracture.

3. The deepest graphitization penetration found was slightly greater than $1 / 10$ inch $(30$ percent of the wall thickness). This was adjacent to the fracture surface.

4. Where graphitization existed, it started at the outside wall surface and proceeded inward, forming a gradient.

5. The presence and pattern of sand deposits in one piece of the fractured pipe length indicated that that piece had been rotated about its longitudinal axis. The presence of the sand does not appear to be related to the failure. 
6. Chemical analysis indicated that the material was an unalloyed grey cast iron.

7. The microstructure and hardness of the material appeared to be normal for grey cast iron.

8. The fracture appears to have initiated at the top of the pipe.

9. The apparent cause of failure was the application of an external load which produced a bending stress in an area weakened by graphitization.

\section{ACKNOWLEDGEMENT}

Messrs. C. H. Brady and I. C. Smith of the Mechanical Properties section performed the metallographic specimen preparation, and Mr. Smith performed the hardness measurements.

\section{REFERENCE}

1. Metals Handbook, American Society for Metals, Eighth Edition, Volume 1, 1961. 


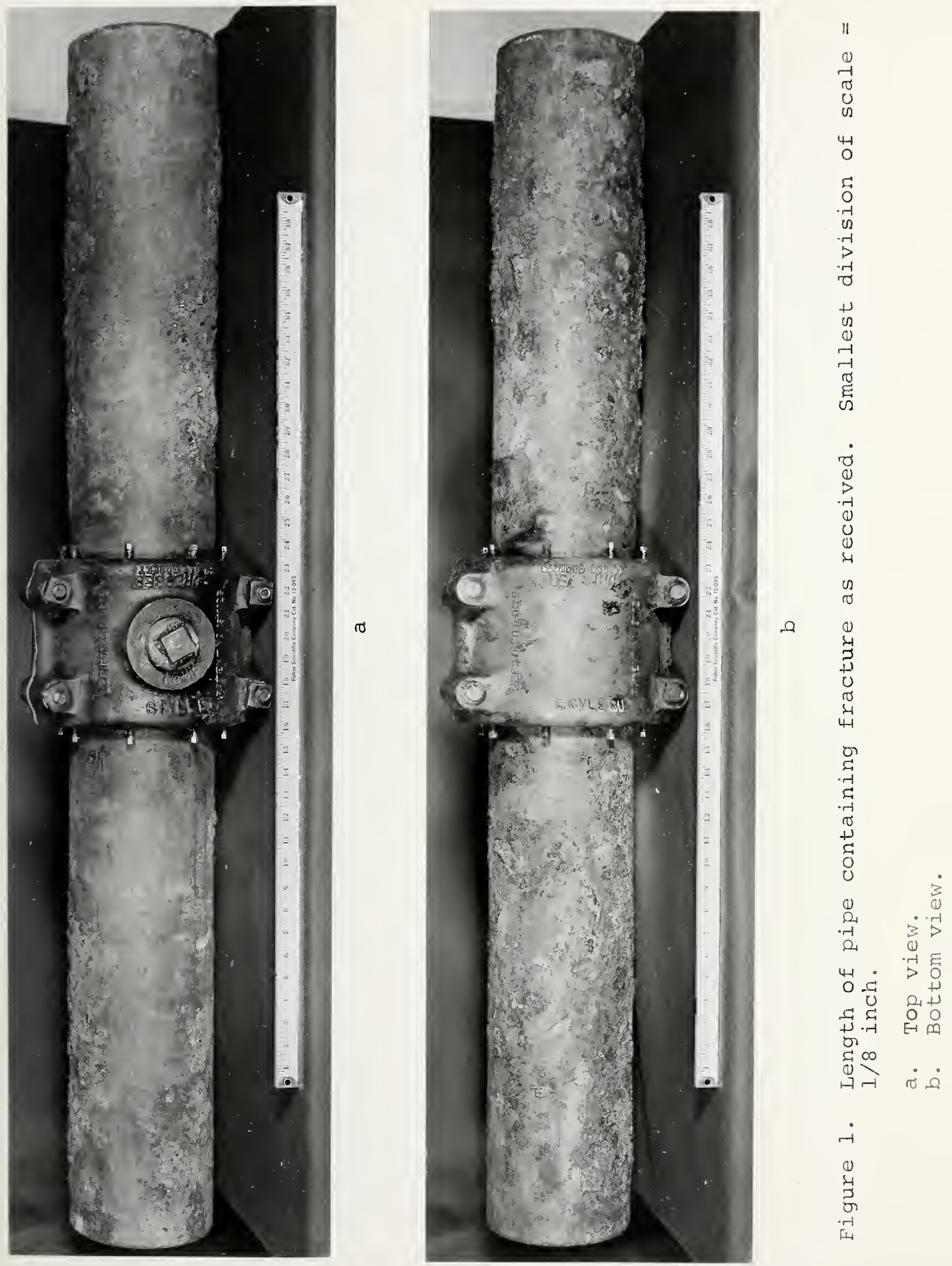



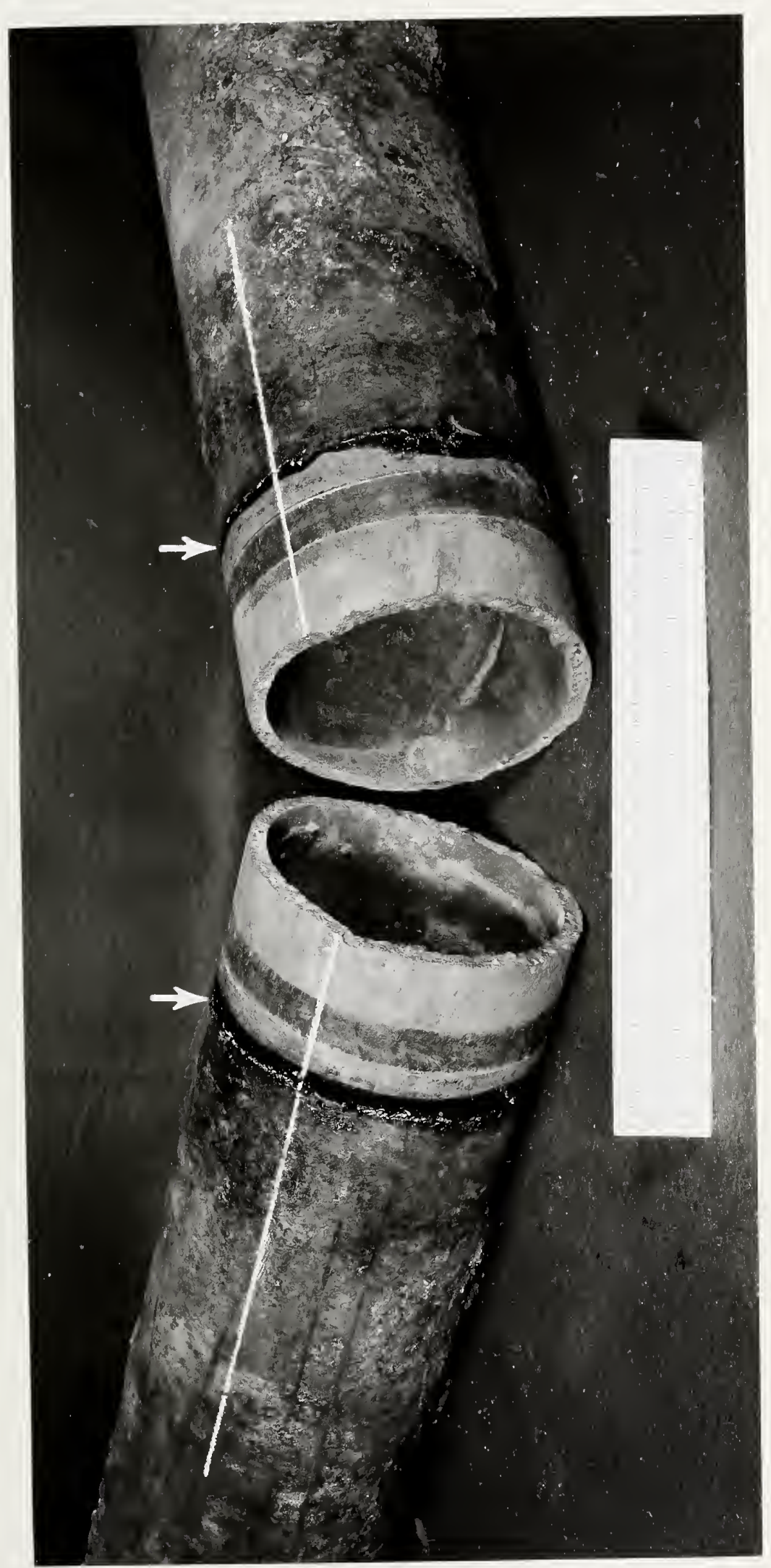

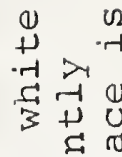

(1) 4 .

त 4 i 3

E组

$\Omega$

- $\infty 00$ (1) 4

उ 0

(1) (1) $\cdot$ त्

$>$ मा

O

है (1)

(1) ह थ

- ${ }_{3}^{3}$ E-

का 0

द्व 40

- $न$ मे ठठ

r- $00+$

गु न्न थ

O U

$0 \mathrm{OH}+$ द U 0

(1) न्न म ह

I)

ज 02

둥

$+\pi$ उ 3

$3 \Omega$ O

(1) (1).न्न

लित्र - त. E- $\Omega$ ल है, 4.00 ० (1) द 囚 0. म. ט.न대 (1) $\Omega+1$ (1) (1) $=$ ? (1) 1100 $0,+\frac{5}{3}$ व 41 . मु 0 व म) 0 다 $0+0$ (1) लि 4. 4 10 3 + 0 요 3050.4 TH 0 ro 0 (1) 0 ह्र सम 0 मान

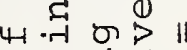
0 द. ज. उ 1 त (1) द्व -

$\dot{N}$

(1)

3 



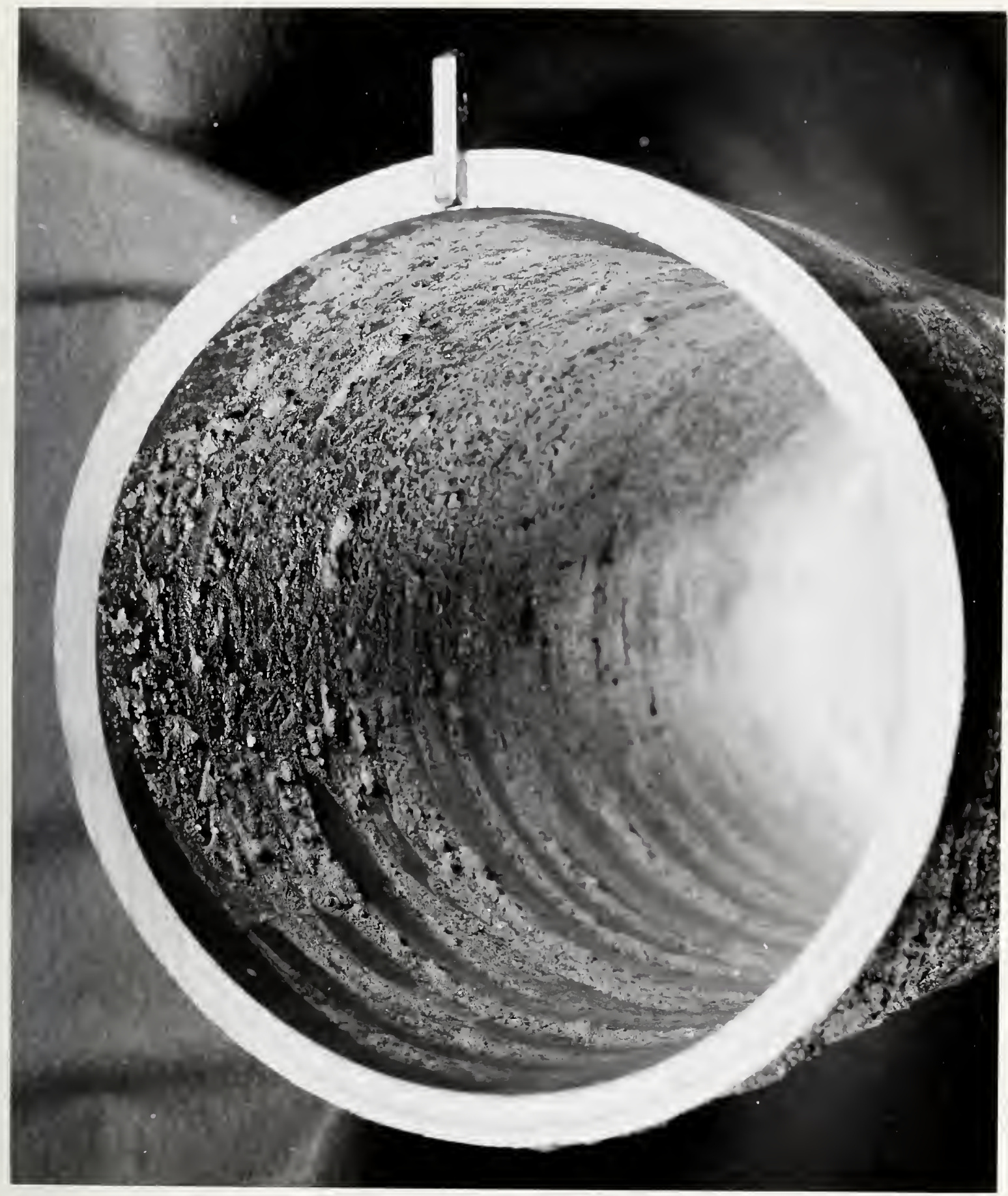

Figure 3. View of the inside of one of the fractured pieces of pipe showing the sand deposits primarily between six o'clock and twelve o'clock. The marker is at the twelve o'clock (top) position of the pipe as it was located in service. $\mathrm{X} 1$ 



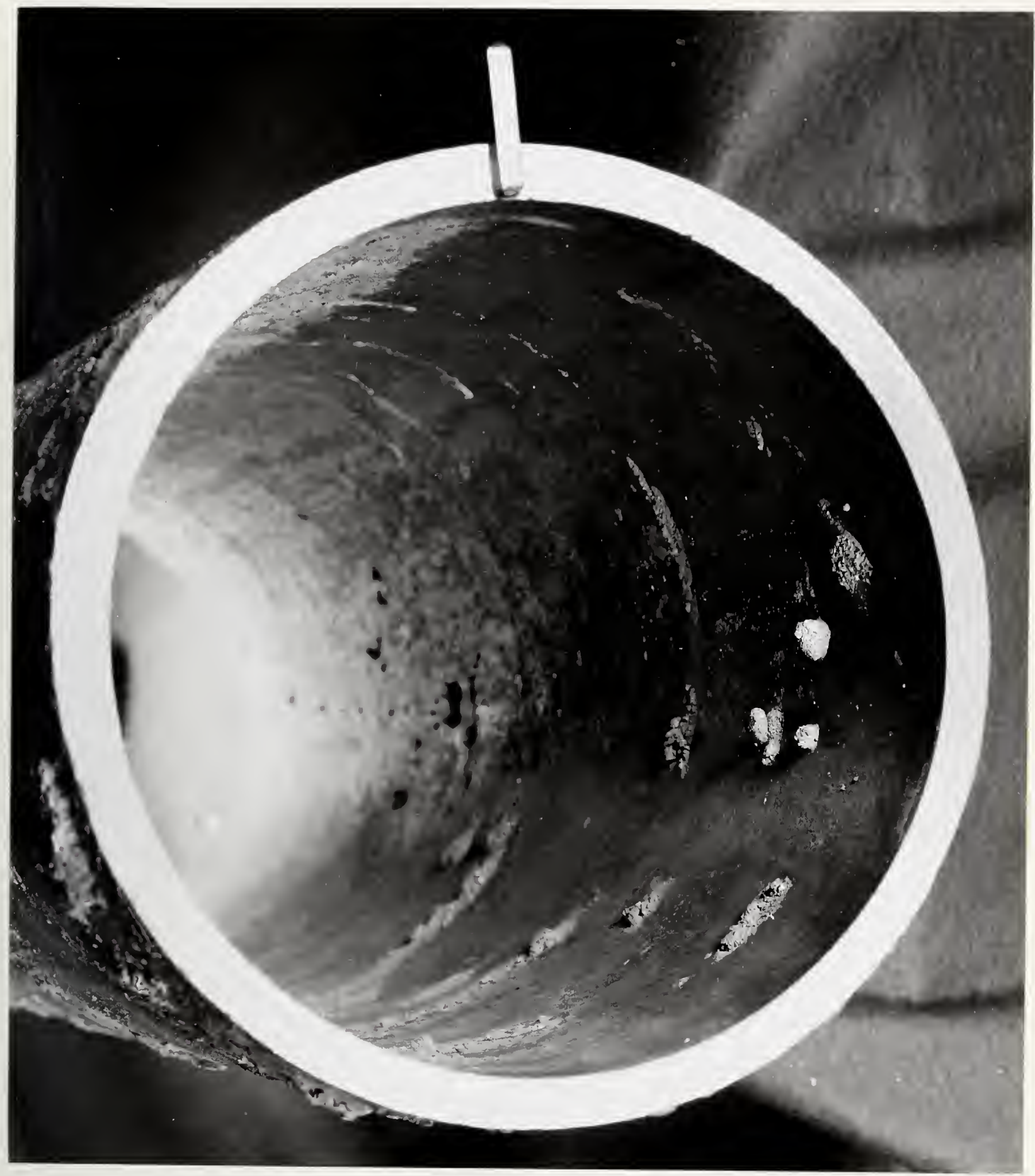

Figure 4. View of the inside of the same fractured piece of pipe as shown in figure 3 showing the sand deposits primarily between twelve o'clock and six $0^{\prime}$ clock. The marker is at the twelve $0^{\prime} \mathrm{clock}$ (top) position of the pipe as it was located in service. $\times 1$ 



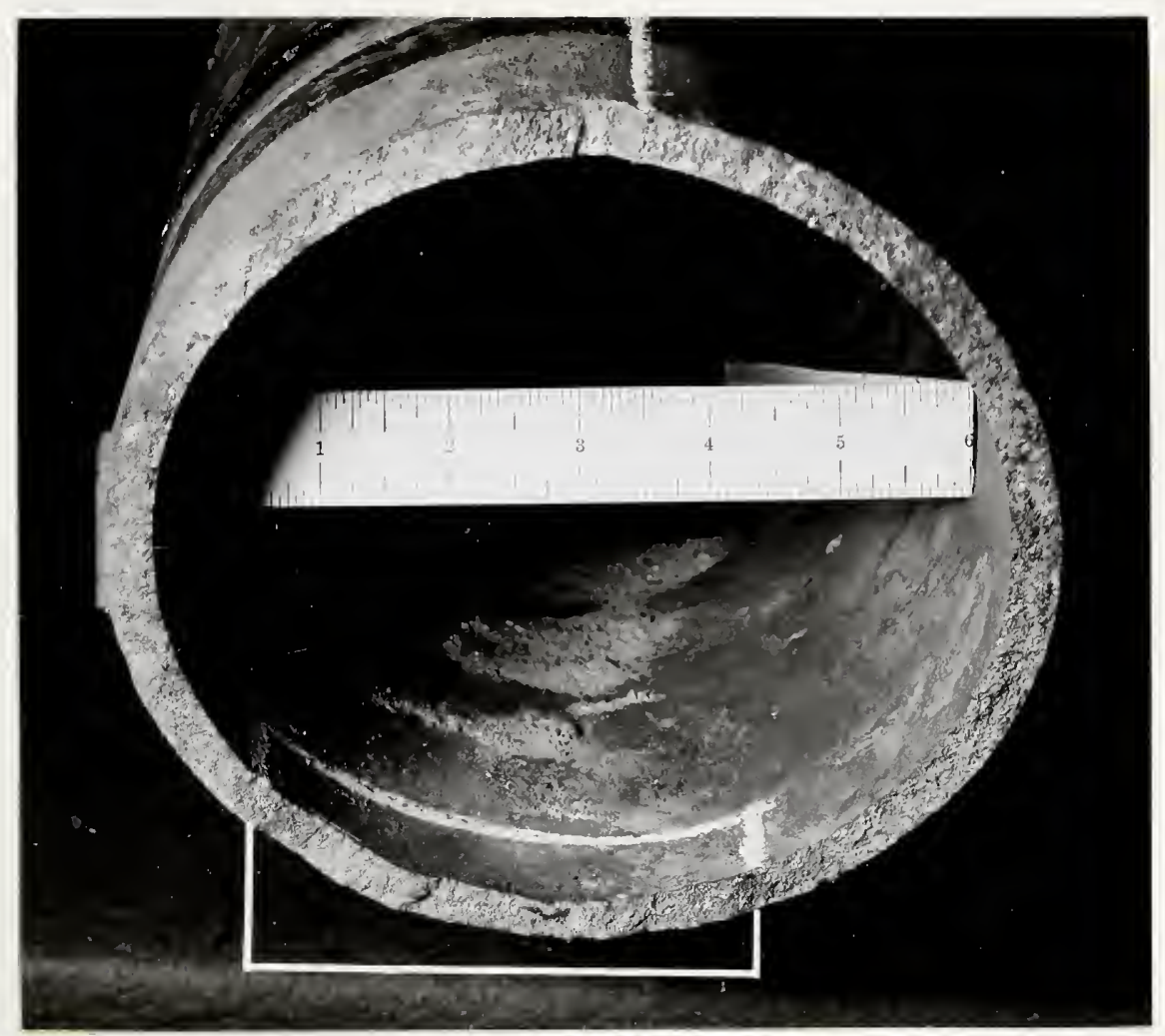

Figure 5. One of the fracture faces. Bracketed region had the appearance of fresh fracture. Unbracketed region was covered with what appeared to be yellow clay soil. Smallest division of scale $=1 / 16$ inch.

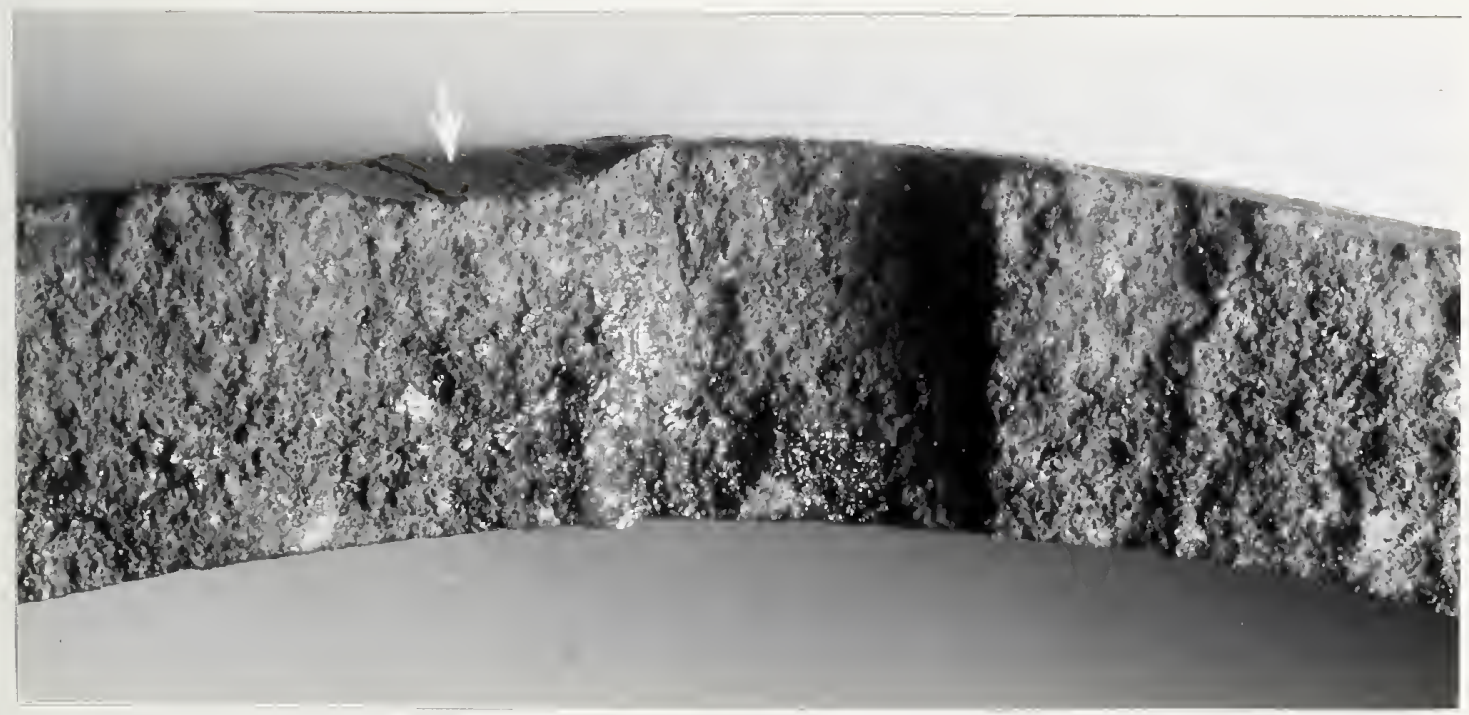

Figure 6. Fracture surface at top of pipe. Arrow indicates location of missing chip(s). X 4 



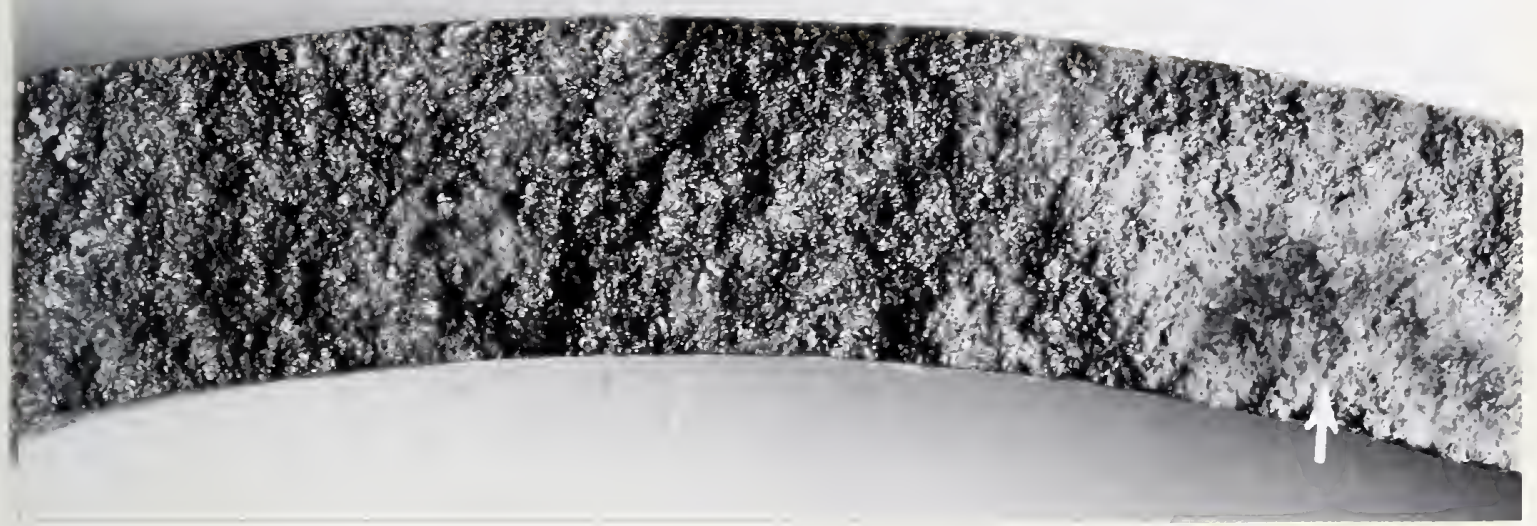

a

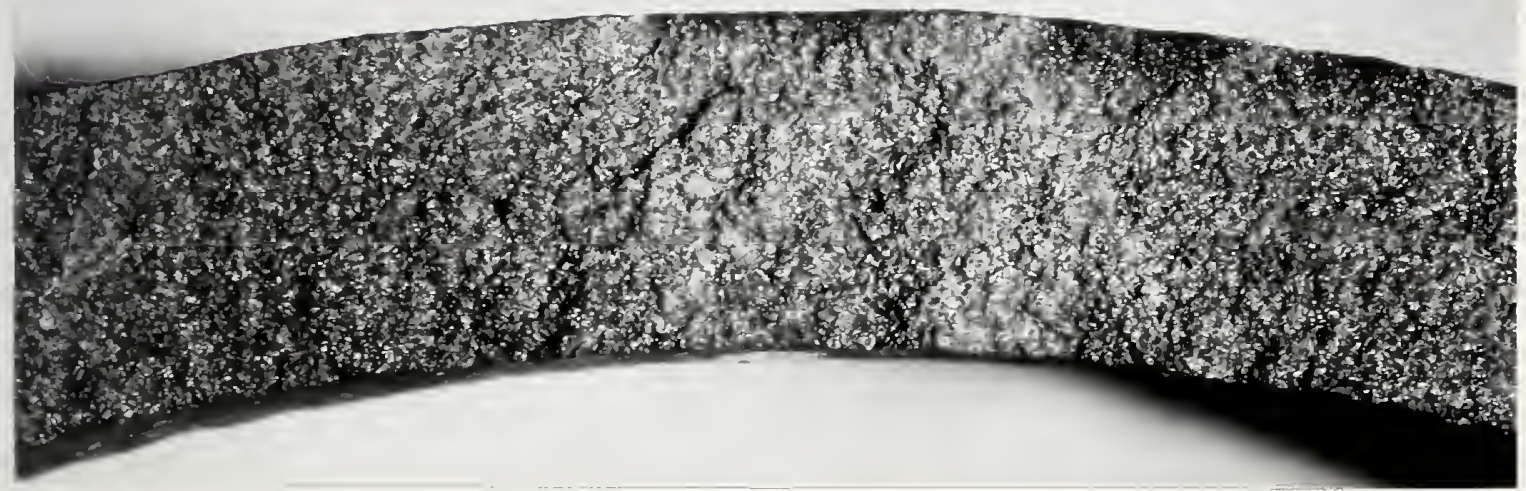

$\mathrm{b}$

Figure 7. Part of one of the fracture surfaces. X 4

a. Fracture surface before cleaning. Arrow indicates area of waxy appearing substance.

b. Same area of fracture surface after cleaning. 



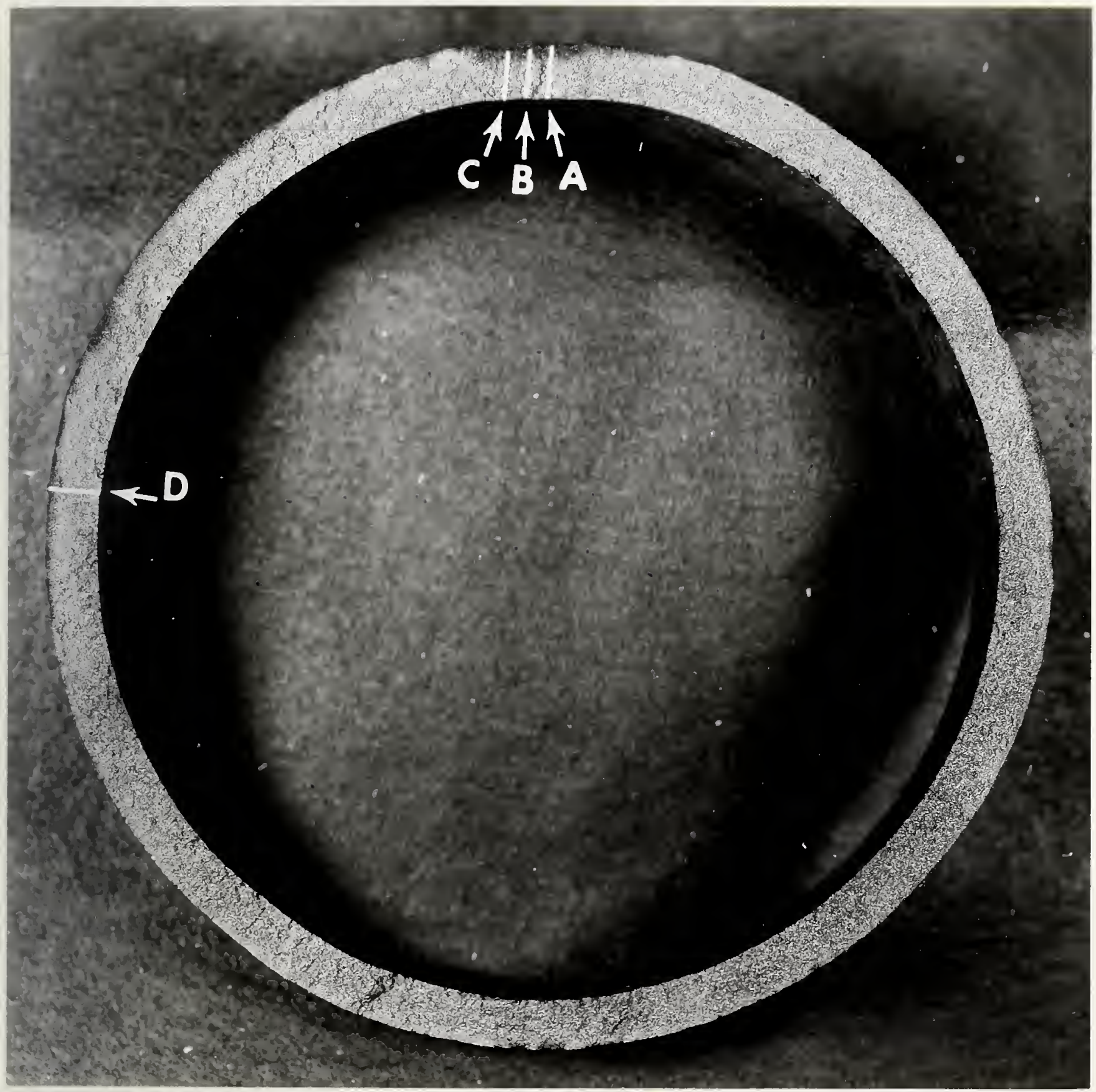

Figure 8. Entire fracture surface after cleaning. Arrows A, B, C, and $D$ indicate locations of longitudinal cross sections cut from the pipe for macroscopic and metallographic examinations. Top of pipe is at top of photograph. X 1 




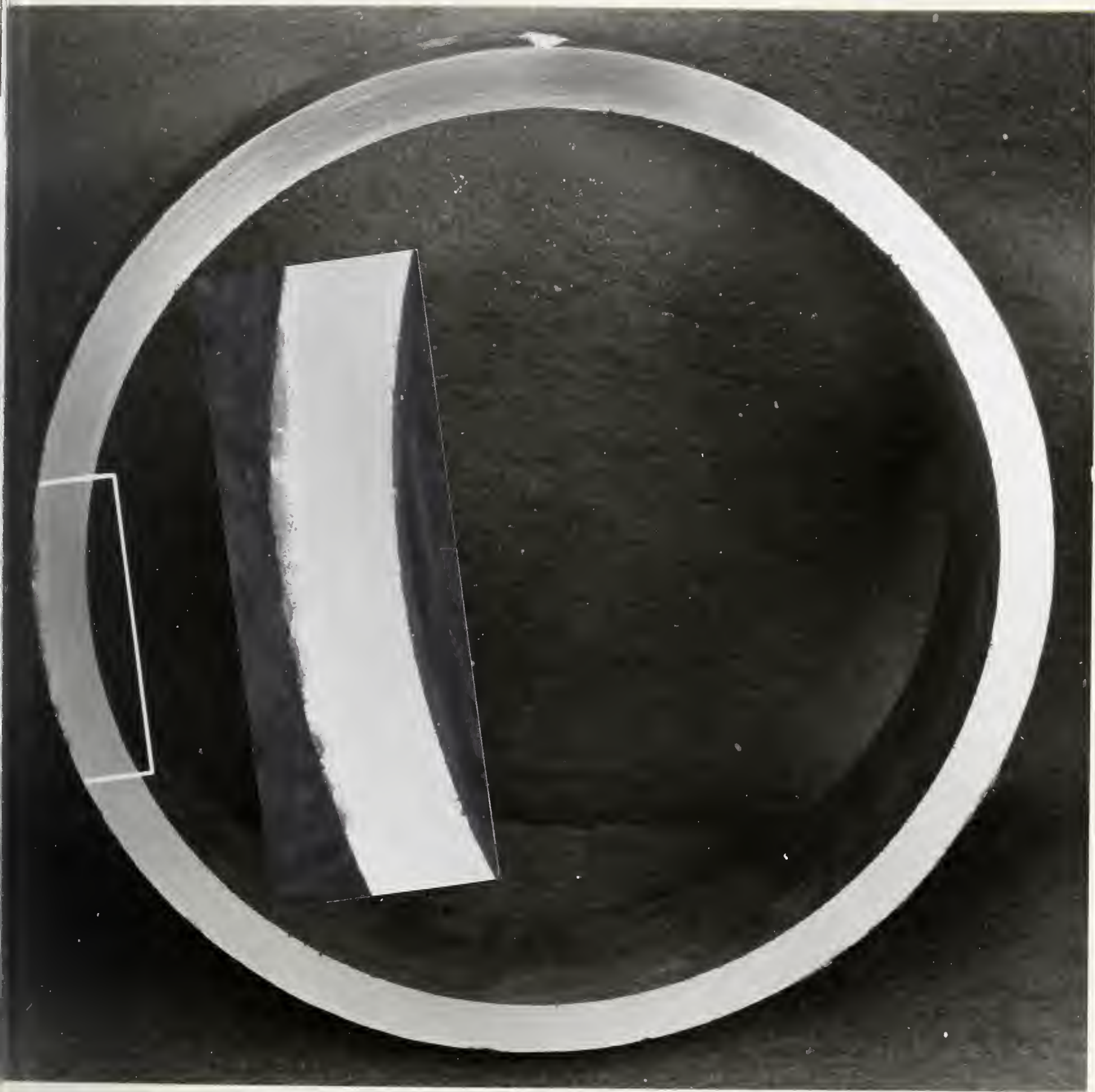

Figure 10. Polished transverse slice about one inch from the fracture surface. Top of pipe is at top of figure. Some areas of graphitization can be seen adjacent to the outside surface of the pipe. These areas are darker than the adjacent material where there is no graphitization. The bracketed area contains the deepest penetration of graphitization in this slice. This area is shown at a higher magnification ( $x$ 2) in the insert. $X 1$ 



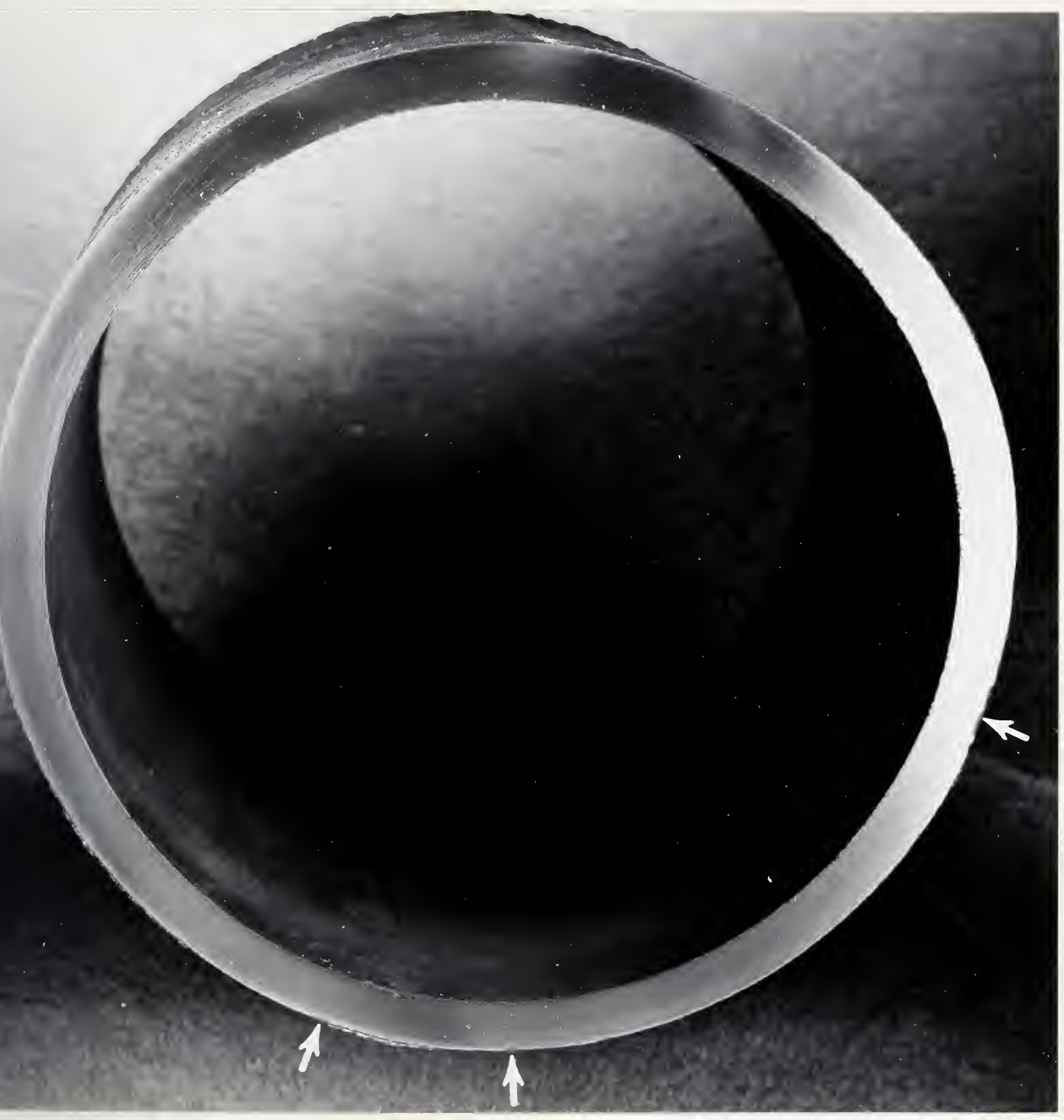

Figure 11. Polished transverse slice about eight inches from the fracture surface. Top of pipe is at top of figure. Some areas of graphitization (arrows) can be seen adjacent to the outside surface of the pipe. These areas are darker than the adjacent material where there is no graphitization. $\mathrm{X} 1$ 


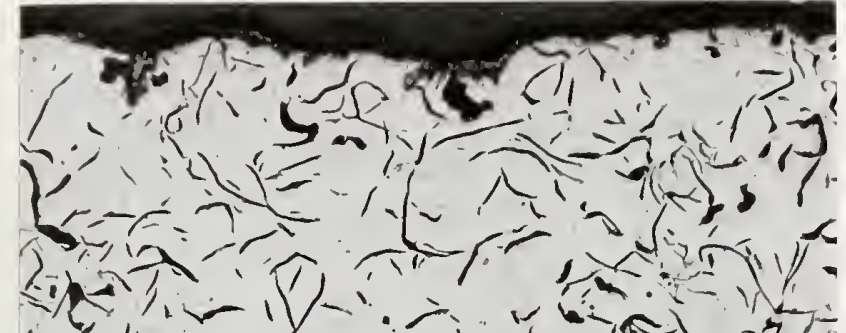
20 依

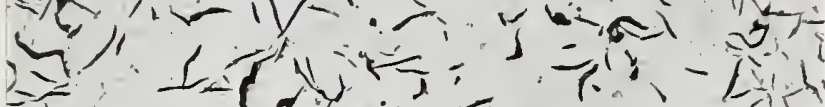

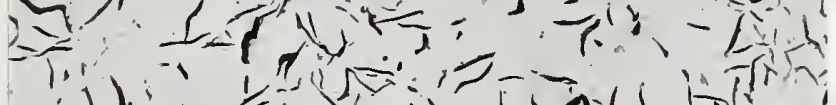
(1) ren $\Rightarrow$, ,

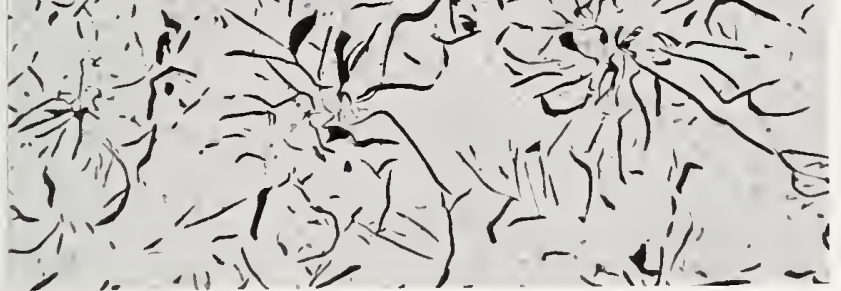

(t) a a $1=0$ r.m. 1,

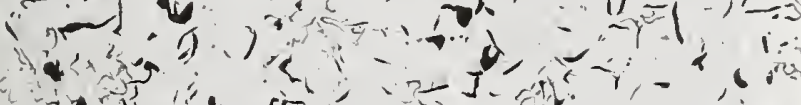
$5 \cos (0)$ or, $1,0,0$

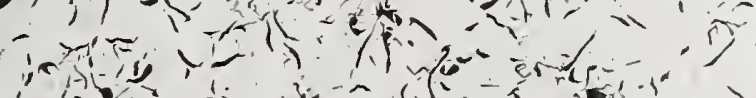
*

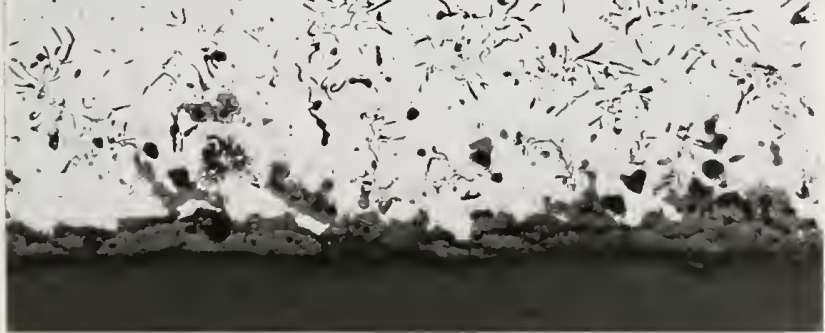
a $\infty$

$c$
0
0
0
0
0
0

(1)

. 



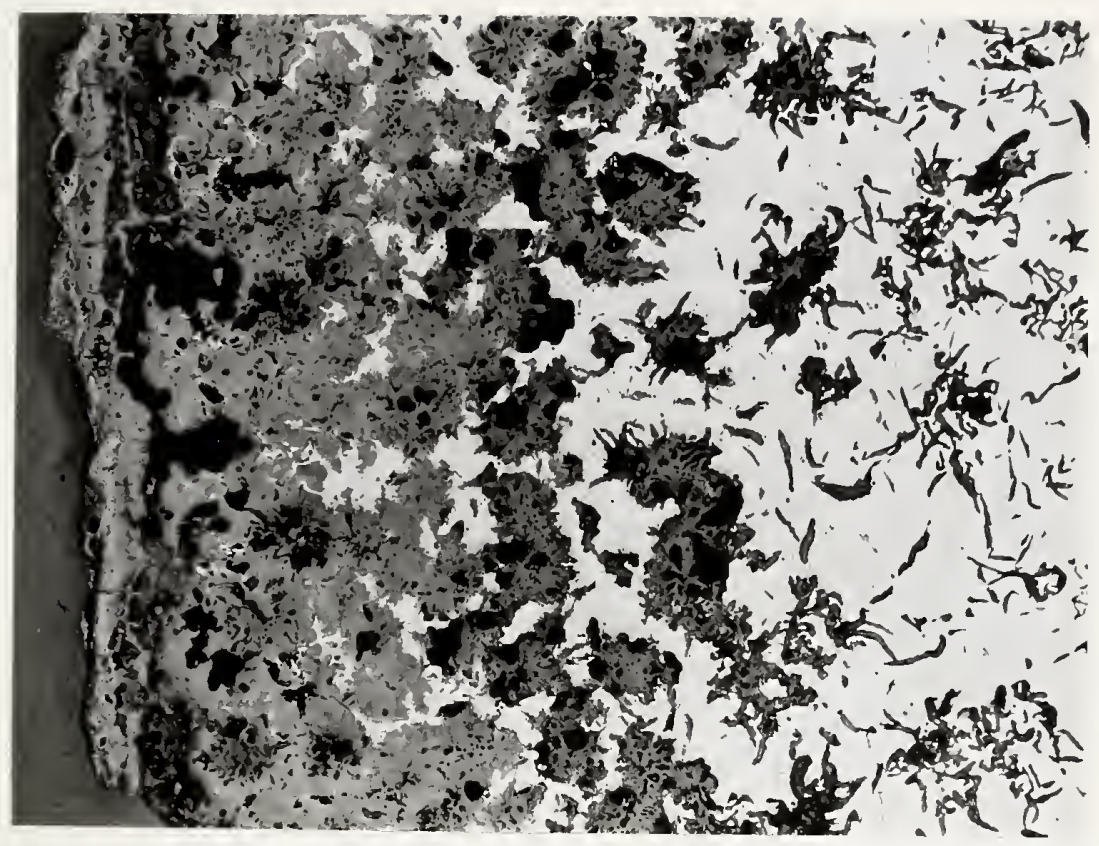

Figure 13. Unetched field from cross section D showing graphitization gradient. Graphitization is essentially complete at the far left. There is no graphitization at the far right. $\mathrm{X} 40$

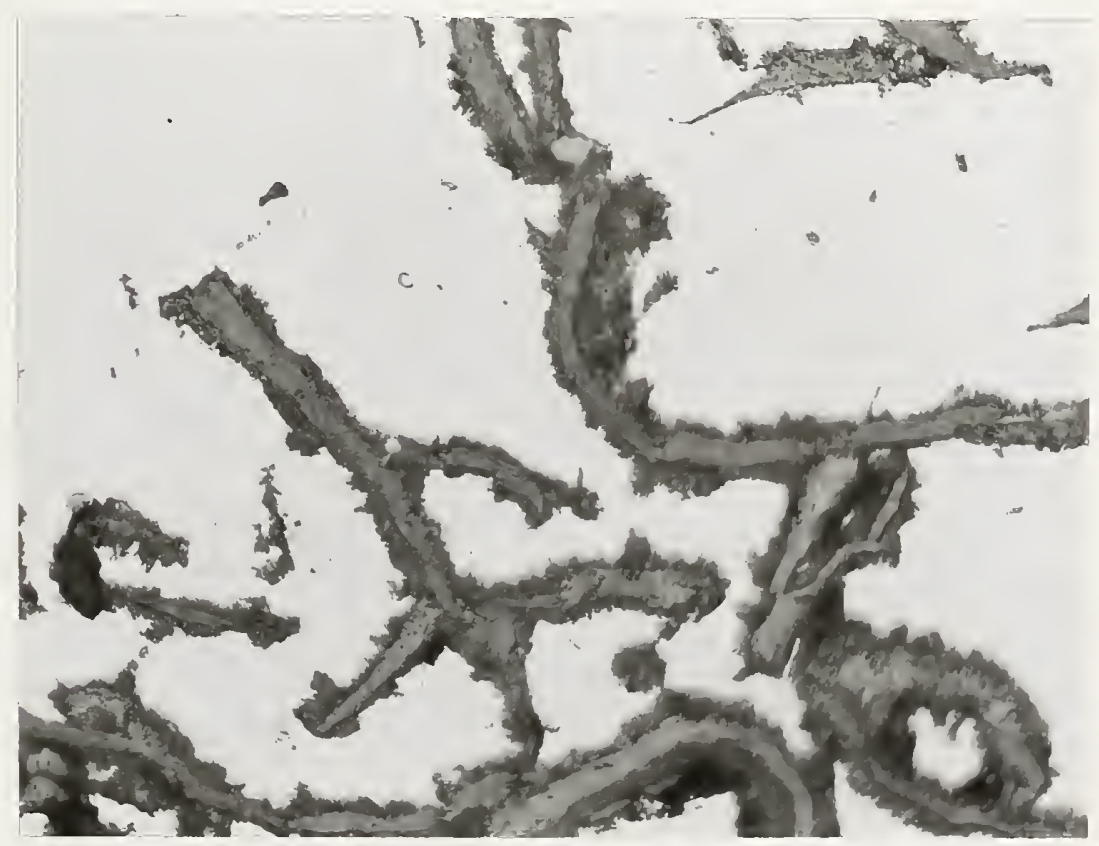

Figure 14. Unetched field from cross section B. Graphitization is just beginning here. There is a considerable amount of corrosion product surrounding the graphite flakes. X 500 


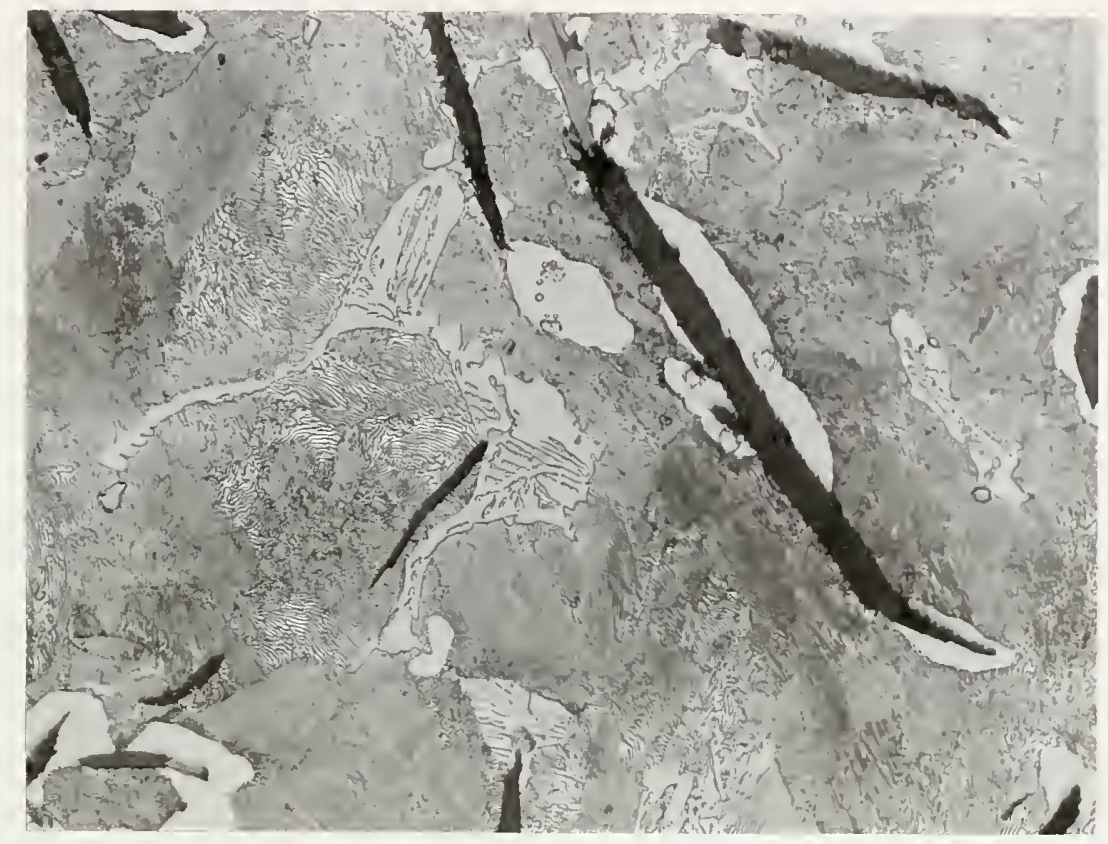

Figure 15. Etched field from cross section D near inside wall surface. Microstructure consists of graphite flakes partially surrounded by ferrite in a matrix of pearlite and iron-iron phosphide eutectic. Etch: 3\% nital. X 500

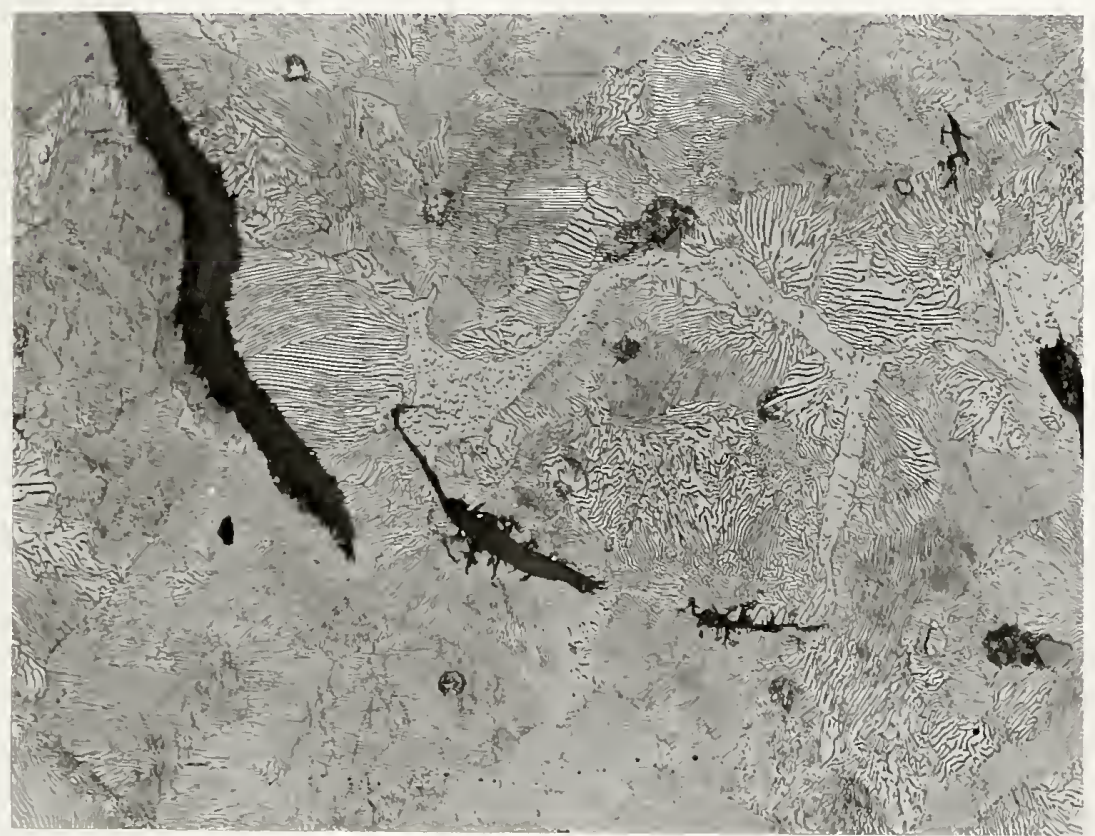

Figure 16. Etched field from cross section D about midway between inside and outside wall surfaces. Microstructure consists of graphite flakes in a matrix of pearlite and iron-iron phosphide eutectic. Etch: 3\% nital. X 500 


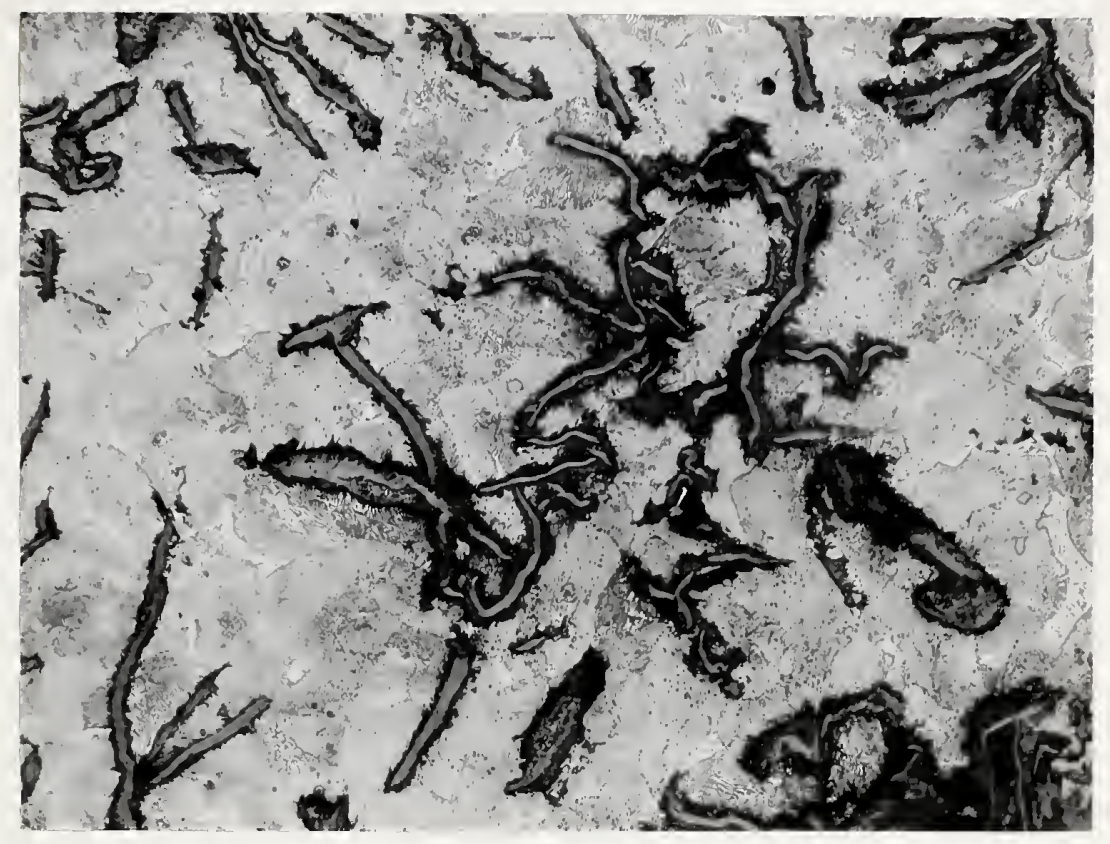

Figure 17. Etched field from cross section D in an area where graphitization is beginning. The graphite flakes are surrounded by corrosion product. The matrix is primarily pearlite and iron-iron phosphide. Etch: 3 nital. X 200

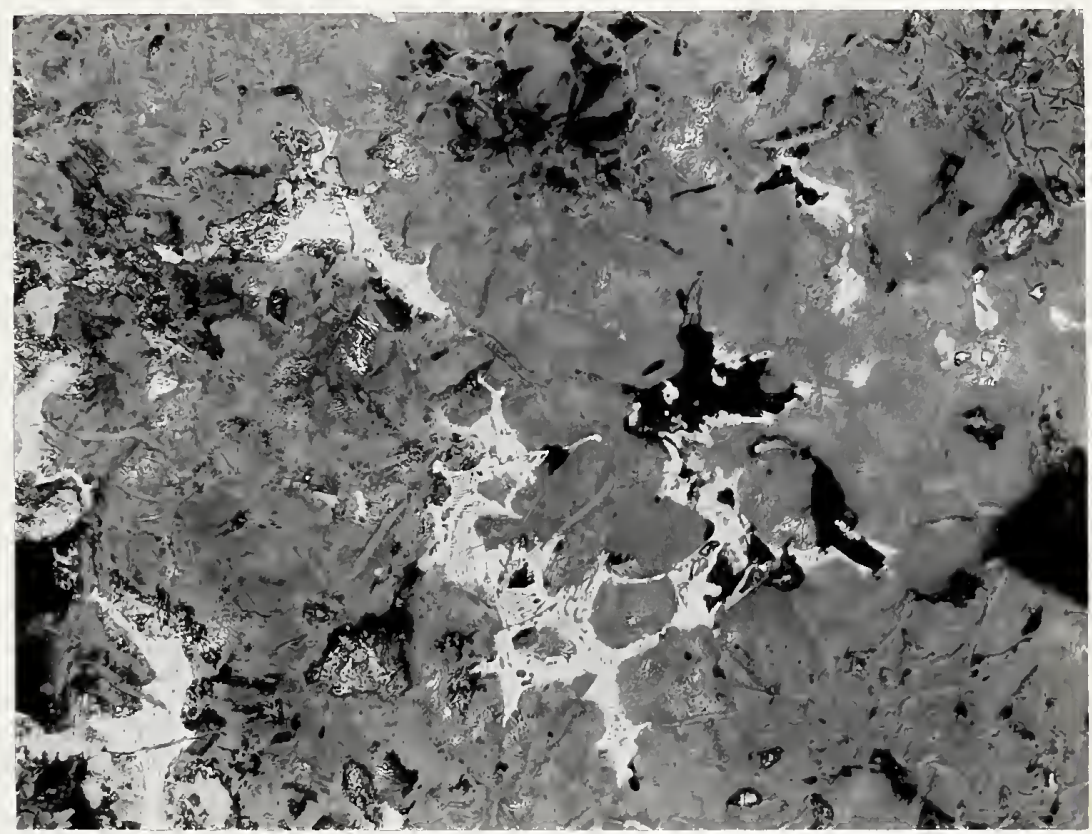

Figure 18. Etched field from cross section D in an area where graphitization is nearly complete. Small patches of the matrix remain. Etch: 3\% nital. X 200 

=ORM NBS. I14A (1.71)

U.S. DEPT. OF COMM.

BIBLIOGRAPHIC DATA SHEET

1. TUBLICATION OR REPORT NO.

NBSIR 73-160

2. Gov't Accession

3. Recipicnt's Accession Nu.

4. T11LE ANB SUHT1T11:

EXAMINATION OF FAILED SIX INCH CAST IRON PIPE NATURAL GAS MAIN, ATLANTA GAS LIGHT COMPANY, ATL $\triangle N T A$, GEORGIA

7. AUTHOR(S)

T. Robert Shives

9. PERFORMING (IRGANIZATION NAME ANI) ADDRESS

NAT IONAL BURFAU OF STANDARDS

DEPARTMENT OF COMMERCE

W'ASHINGTON, D.C. 20234

5. Publication Daste

April, 1973

6. Performing. Organization Code

8. 'erforning Organization NBSIR 73-160

10. Project/Task/Work Unit No. 3120415

11. Coneract/Grant No.

12. Sponsoring Organizarion Name and Address

Bureau of Surface Transportation

National Transportation Safety Board

Department of Transportation

Washington, D. C. 20591

13. Type of Report \& Period

Covered

Failure

Analysis Report

14. Sponsoring Agency Coje

15. SUPPLEMENTARY NOTES

16. ABSTRACT ( A 200-word or less factual summary of most significant information. If document includes a significant bibliography or literature survey, mention it here.)

A five foot length of six inch grey cast iron pipe from a natural gas main in Atlanta, Georgia, was submitted for examination. The pipe had fractured at the approximate center of the sulumitted length. The fracture appeared to have initiated at the top of the pipe and occurred in at least two stages, with the region at the bottom of the pipe being the last part to fail. Graphitization (corrosion), penetrating up to 30 percent of the wall thickness in one area adjacent to the fracture, was found in all cross sections examined, although most of the material examined was free of graphitization. The likely cause of failure was the application of an external load to produce a bending stress in an area weakened by graphitization.

17. KI:Y WORDS (A/phabctical order, separated by semicolons)

Cast iron; corrosion; gas pipe; graphitization

18. AVAII.ABILITY STATEMENT

[] UNIMMITED.

[X]FOR OI:IICIAL DISTRIBUTION. DO NOT RELEASE TO NTIS.

\begin{tabular}{|l|c|}
$\begin{array}{l}\text { 19. SECURITY CLASS } \\
\text { (THIS REPORT) } \\
\text { UNCLASSIFIED }\end{array}$ & 21. NO. O1: PAGES \\
\hline $\begin{array}{l}\text { 20. SECURITY CLASS } \\
\text { (THIS PAGE) } \\
\text { UNCL ASSIFIED }\end{array}$ & 22. Price \\
\hline
\end{tabular}


